\title{
GPX1 Gene
}

National Cancer Institute

\section{Source}

National Cancer Institute. GPX1 Gene. NCI Thesaurus. Code C55288.

This gene plays a role in the inhibition of oxidative stress and increases cellular resistance to toxic challenges. 